\title{
De novo SCNIA géndeletio terápiarezisztens Dravet-szindrómában
}

\author{
Bene Judit dr. ${ }^{1,2}$ - Hadzsiev Kinga dr., ${ }^{1,2}$ - Komlósi Katalin dr. ${ }^{1}$ \\ Kövesdi Erzsébet dr., ${ }^{1,2}$ - Mátyás Petra ${ }^{1}$ - Melegh Béla dr. ${ }^{1}$
}

${ }^{1}$ Pécsi Tudományegyetem, Általános Orvostudományi Kar, Klinikai Központ, Orvosi Genetikai Intézet, Pécs ${ }^{2}$ Szentágothai János Kutatóközpont, Pécs

\begin{abstract}
A Dravet-szindróma vagy régebbi nevén súlyos csecsemókori myoclonusos epilepszia igen ritka formája az epilepsziának. Az autoszomális domináns öröklésmenetet mutató kórkép leggyakoribb oka a feszültségfüggő nátriumcsatorna alfa-1 alegységet kódoló $S C N 1 A$ gén mutációja. Az esetek többségének hátterében de novo pontmutáció áll, azonban néhány betegben a gén kópiaszám-változása figyelhető meg. Az SCNIA gén által kódolt fehérje a neuronalis ingerület kiváltásában és vezetésében játszik szerepet. A génmutációk többsége következtében kialakuló funkcióvesztés a neuronalis hálózat fokozott ingerelhetőségéhez vezet, ami az epilepsziás görcsök kialakulását eredményezi. A szerzők intézetében 2013 óta elérhető az SCNIA gén kópiaszám-változásának (deletio/duplikáció) vizsgálata is a gén teljes szekvenálása mellett. Jelen közleményben egy 7 éves beteg esetét mutatják be, aki 2 éves betegút után került intézetükbe. A molekuláris genetikai vizsgálat, amely de novo SCNIA géndeletiót detektált heterozigóta formában, fényt derített a rendkívül terápiarezisztens görcsök hátterében az $S C N 1 A$ gén asszociálta monogénes epilepszia szindrómára. Orv. Hetil., 2015, 156(49), 2009-2012.
\end{abstract}

Kulcsszavak: Dravet-szindróma, terápiarezisztens epilepszia, SCNIA, MLPA

\section{De novo SCNIA gene deletion in therapy-resistant Dravet syndrome}

\begin{abstract}
Severe myoclonic epilepsy in infancy (Dravet's syndrome) is a very rare form of epilepsy. Mutations of SCNIA gene encoding voltage-gated sodium channel alpha- 1 subunit are major causes of the autosomal dominant disorder. Most cases are associated with a de novo point mutation, but some patients have copy number variations. The protein encoded by the SCNIA gene plays a role in the generation and propagation of action potentials. Loss of function caused by the majority of gene mutations leads to hyperexcitability of the neuronal network that finally results in the formation of the epileptic seizures. Molecular genetic test for copy number variations of SCNIA gene is available in the department of the authors since 2013 besides sequencing analysis of the whole gene. This article presents the case of a 7-year-old patient with two years of recorded patient history outside of the author's department. Molecular genetic test, which detected a de novo SCNIA gene deletion in heterozygous form, revealed SCNIA gene associated monogenic epileptic syndrome being in the genetic background of therapy-resistant seizures.
\end{abstract}

Keywords: Dravet syndrome, therapy-resistant epilepsy, SCNIA, MLPA

Bene, J., Hadzsiev, K., Komlósi, K., Kövesdi, E., Mátyás, P., Melegh, B. [De novo SCNIA gene deletion in therapy-resistant Dravet syndrome]. Orv. Hetil., 2015, 156(49), 2009-2012.

(Beérkezett: 2015. szeptember 15.; elfogadva: 2015. október 8.)

\begin{abstract}
Rövidítések
array CGH = array komparatív genomhibridizáció; $\mathrm{CNV}=$ kópiaszám-változás; GAG = glükóz-aminoglikán; GEFS+ = generalizált lázgörcs plusz szindróma; MLPA = multiplex ligatiofüggő próbaamplifikáció; MR-vizsgálat = mágneses rezonanciás vizsgálat; $S C N I A$ = feszültségfüggő nátriumcsatorna alfa-1 alegységet kódoló gén
\end{abstract}

Az epilepszia az életminőség és a társadalmi beilleszkedés szempontjából speciális kórkép. Előfordulási gyakorisága felnőttekben 0,5 , gyermekekben 0,9-1\%-ra tehető, az első tünetek megjelenése az esetek 60-70\%-ában 0-18 éves kor közé esik. Etiológiáját tekintve rendkívül változatos, a veleszületett formák hátterében agyi strukturális 
eltérés vagy genetikai faktor állhat, azonban ezen belül is rendkívüli heterogenitást mutat. Családi és ikertanulmányok eredményei azt mutatják, hogy az epilepsziás esetek közel 30-40\%-ának áll a hátterében valamilyen genetikai eltérés $[1,2,3]$. A primeren genetikai eredetú esetek körülbelül 1\%-át teszik ki a monogénes formák, amelyek egyik jelentős csoportját az ioncsatornagének eltérései okozzák (GABRD, GABRD2, SCNIA, SCNIB, SCN2A, SCN9A) $[4,5]$.

Az ioncsatornagének közül az $S C N 1 A$ gén mutációi a leggyakoribbak [5]. Maga a gén a 2q24.3-as kromoszómarégióban fordul elő, 26 exont tartalmaz és egy 2009 aminosavból álló transzmembránfehérjét kódol. A feszültségfüggő nátriumcsatornáknak nélkülözhetetlen szerepük van a neuronokban az akciós potenciál inicializálásában és terjedésében. A fehérje 4 homológ doménje a membránon belül összekapcsolódva egy nátriumra permeabilis pórust alkot, amelyen keresztül a nátriumionok a koncentrációgradiens irányába áramlanak az akciós potenciál terjedése alatt. A génben előforduló mutációk többsége fehérjetrunkációt és ezáltal funkcióvesztést eredményez, amely a neuronalis hálózat fokozott ingerelhetôségéhez vezet [6].

A Dravet-szindróma vagy régebbi nevén súlyos gyermekkori myoclonusos epilepszia igen ritka formája az epilepsziának, öröklődése autoszomális domináns menetet mutat. Előfordulásának gyakorisága 1:20 000, illetve 1:40 000, és férfiaknál gyakoribb, mint a nőknél (2:1), a tünettana széles klinikai spektrumot mutat [7]. Az elmúlt évtizedben került igazán az érdeklődés középpontjába, amióta a betegség genetikai háttere is ismertté vált, és így egyre több beteg lett azonosítható [8]. A betegek több mint 70\%-ában a feszültségfüggő nátriumcsatorna alfa-1 alegységet (NaVl.1) kódoló SCNIA gén mutációja mutatható ki. Az esetek többsége de novo trunkációval vagy misszenz mutációval van összefüggésben. Néhány betegben az SCN1A gén kópiaszám-változása fordul elő, ami azonban hagyományos szekvenálással nem mutatható ki. Ennek detektálása specifikus technikát igényel, mint például a multiplex ligatiofüggő próbaamplifikációt (MLPA) vagy ezzel ekvivalens technológiát [9]. Az intenzív kutatások ellenére azonban a Dravet-szindróma 20-30\%-ának az etiológiája továbbra is tisztázatlan [10].

Intézetünkben 2013 óta érhető el az SCN1A gén kópiaszám-változásának (deletio/duplikáció) a vizsgálata. Közleményünkben egy 7 éves betegünk esetét mutatjuk be, aki 2 éves betegút után került intézetünkbe. A molekuláris genetikai vizsgálat, amely egy de novo SCNIA géndeletiót detektált heterozigóta formában, fényt derített a rendkívül terápiarezisztens görcsök hátterében az SCN1A gén asszociálta monogénes epilepszia szindrómára.

\section{Az SCN1A gén deletio/duplikáció vizsgálata}

A betegek molekuláris genetikai vizsgálatait EDTA-val alvadásgátolt perifériás vér fehérvérsejtjeiből, rutin kisózásos módszerrel kinyert DNS-mintából végeztük el. Azoknál a betegeknél, akiknél az SCN1A gén pontmutációs vizsgálata során nem találtunk patogén eltérést, elvégeztük az SCNIA gén nagyobb átrendeződéseinek vizsgálatát MLPA-technikával kereskedelemben kapható kittel, a gyártó leírása alapján (MRC Holland, Amszterdam, Hollandia). Maga a technika, amely exonspecifikus ligálási lépésból, fluoreszcensen jelölt univerzális primerekkel történő PCR-amplifikációból és a keletkezett termékek fragmentanalíziséből áll, egy vagy több exon, vagy akár a teljes gén kópiaszám-változásának (deletio/ duplikáció) kimutatására alkalmas.

Intézetünkben 2012 óta végezzük az SCN1A gén pontmutáció vizsgálatát és 2013 óta a gén nagyobb átrendeződéseinek vizsgálatát epilepszia tüneteit mutató betegek és családtagok vérmintájából. A vizsgálatokra beérkezett vérminták nagy részét az intézetünk genetikai tanácsadójában részletes fenotípuselemzésen átesett betegek mintái képezik, kisebb részt a minták külső intézetekból érkeztek laboratóriumunkba. A humángenetikai törvénynek megfelelően genetikai tanácsadást követően a betegek írásos beleegyezésüket adták a genetikai vizsgálat elvégzéséhez, valamint adataik tudományos közleményekben történő felhasználásához.

Ez idáig 26 beteg és két családtag molekuláris genetikai vizsgálatát végeztük el az $S C N 1 A$ gén átrendeződésének (deletio/duplikáció) az irányában. Vizsgálataink során egy esetben tudtunk eltérést kimutatni, a teljes gént érintő deletiót detektáltuk heterozigóta formában. A szülők vizsgálata negatív eredménnyel zárult, ami arra utal, hogy a gyermekben talált genetikai eltérés de novo alakult ki.

\section{Esetismertetés}

Betegünk egy jelenleg 7 éves fiú, aki a mater első, zavartalan terhességéből a 39. hétre, 3200 g súllyal, elhúzódó vajúdást követően sectio caesareával, Apgar 5-9 ponttal született. Tracheaszívást és átmeneti maszkos lélegeztetést követően a perinatalis időszak eseménytelenül zajlott. Születésétől kezdve észlelték enyhe generalizált izomhypotoniáját, korai pszichomotoros fejlődése kissé megkésett volt, 10 hónaposan ült, 1 évesen állt, 16 hónaposan járt, majd 18 hónaposan már tisztán beszélt. Ezt követően 18 hónapos kortól észlelik regresszióját. $\mathrm{Az}$ első életévben is jelentkeztek elrévedései, majd első lázgörcse egyéves korában zajlott, később infekciók kapcsán számos különböző típusú görcse jelentkezett. Másfél éves korától láz nélkül is görcsölt, ezek több antiepi- 
leptikumra (valproát, lamotrigin, carbamazepin) is rezisztensnek bizonyultak. Kétéves korában elvégzett koponya-MR-vizsgálat tágabb perivascularis úrök jelenlétét mutatta, amely alapján tárolási betegség irányába diagnosztikus vizsgálatok (vizelet-GAG-ürítés mucopolysaccharidosis irányába) történtek, normális eredménnyel. Rutin anyagcsere-vizsgálatok (szérum- és vizelet-aminosav és vizelet-szervessav) szintén nem mutattak eltérést. Kardiológiai, szemészeti, audiológiai és ortopédiai vizsgálatok során a terápiarezisztens epilepszián kívül egyéb eltérésre nem derült fény. Az epilepszia és pszichomotoros regresszió genetikai hátterének vizsgálata az FMR I és CDKL5 gének eltéréseit, a mitokondriális öröklődésű Leigh-szindrómát, valamint a kreatinszintézis-defektusok lehetőségét kizárta.

Intézetünkben először 3,5 évesen vizsgáltuk betegünket. Fizikális státuszában súlya $18 \mathrm{~kg}(75 \mathrm{pc})$, hossza: $107 \mathrm{~cm}(50 \mathrm{pc})$, fejkörfogata $51 \mathrm{~cm}(+2 \mathrm{SD})$ volt, macrocephalián kívül lényeges dysmorphia nem volt észlelhető, neurológiai vizsgálata ataxiás járást, echolaliát, megkésett beszédfejlődést és mérsékelt generalizált izomhypotoniát mutatott. Családi anamnézise negatív, epilepszia, lázgörcs előfordulása a családban nem ismert.

Betegünk jelenleg ketogén diétát tart, antiepileptikus kezelést évek óta nem kap, az elmúlt hat hónapban görcse nem jelentkezett, regressziója lelassult.

\section{Megbeszélés}

Nemzetközi irodalmi adatok szerint klinikai szempontból az SCNIA gén a legfontosabb a monogénes epilepszia genetikai hátterében szerepet játszó gének közül. A génben előforduló mutációk elsődlegesen Dravetszindrómával társulnak, azonban a generalizált lázgörcs plusz szindróma (GEFS+) esetek körülbelül 10\%-a és néhány ritka epilepsziás encephalopathia is társulhat $S C N 1 A$-mutációval. A gén több mint 700 mutációját írták le mostanáig, amelyek közel 50\%-a az SCNIA haploinsufficientiáját eredményező funkcióvesztéssel járó frameshift, nonszenz, splice-site mutáció, illetve 40\%-a aminosavcserével járó misszenz pontmutáció [5]. Az utóbbi évek kutatásai azonban a betegek egy kis csoportjában a gén kópiaszám-változását (deletio/duplikáció) azonosították a betegség hátterében $[11,12,13]$. A mutációk többsége (85-90\%) de novo alakul ki, az esetek 5-10\%-áért azonban a familiáris mutációk felelősek [5].

Egy betegség kialakulásáért felelős gén egy vagy több exonját érintő deletio vagy duplikáció nem detektálható hagyományos PCR-alapú technikával. Az MLPA az egyik lehetséges diagnosztikai eszköz, amivel lehetőség van a vizsgálandó gén egy vagy több exonját érintő deletiók, duplikációk és egyéb kópiaszám-változások (CNV) kvantitatív detektálására. Az SCNIA gén kódoló pontmutációját nem hordozó Dravet-szindrómás betegek körében végzett MLPA és array komparatív genomhibridizáció- (array CGH) vizsgálatok a betegek 10, 11, illetve 15\%-ában mutattak ki mikrokromoszomális eltérést, ami méretét tekintve az egy exontól az $S C N I A$ génen túlnyúló méretig terjedt. A deletiók jóval gyakrabban fordultak elő ezekben a betegekben, mint a duplikációk $[11,12,13]$.

Az általunk vizsgált gyermekben az MLPA-vizsgálat egy, a teljes gént (exon 1-26) érintő deletiót tárt fel heterozigóta formában. A szülő́k genetikai vizsgálata során nem találtunk eltérést az $S C N 1 A$ gén kópiaszámában, ami azt támasztja alá, hogy az eltérés a gyermekben, az irodalmi adatokkal összhangban, de novo alakult ki.

A Dravet-szindróma tünettana rendkívül széles spektrumot ölel fel, ahogyan a gén mutációs spektruma is rendkívül változatos. Hasonló mutációk igen eltérő fenotípust eredményezhetnek. Az $S C N 1 A$ gén mutációi körében végzett egyes genotípus-fenotípus elemzések szerint súlyos klinikai kép gyakrabban volt megfigyelhető trunkált alfa alegységet okozó nonszenz mutációk és azon misszenz mutációk esetében, amelyek a pórusalkotó régióban az aminosav-polaritást, következésképpen a nátriumáramot módosították [14]. Egy másik, napjainkban végzett átfogó tanulmány azt állapította meg, hogy a misszenz mutációval összehasonlítva a trunkált mutációk az elhúzódó, valamint a myoclonusos rohamok és az atípusos absence-ok korábbi életkorban való megjelenésével voltak összefüggésben [15]. Wang és mtsai ezzel szemben az SCNIA génen túlnyúló mikrokromoszomális deletiót hordozó betegek esetében nem talált fenotípusbeli eltérést a deletiót és egyéb pontmutációt hordozó betegek között [13].

Terápiás szempontból a hagyományos antiepileptikumok nem vagy csak korlátozottan alkalmazhatók Dravetszindrómás betegekben. Habár a ketogén diéta hatásának pontos mechanizmusa még nem ismert, jelen betegünknél mindenképpen jelentős javulást, a tünetek mérséklését eredményezte.

Noha az SCNIA gén átrendeződésének előfordulása nem olyan gyakori, 10-15\% körüli irodalmi adatok szerint, másodvonalbeli tesztként érdemes elvégezni az MLPA-vizsgálatot a pontmutációra negatív betegeknél. A jelenlegi diagnosztikus kritériumok szerint a Dravetszindróma nem diagnosztizálható korai stádiumban, azonban az MLPA-vizsgálatok eredménye a minél korábbi diagnózis felállításában is segíthet, különösen azokban a betegekben, akiknél hosszú ideje láz indukálta görcsök fordulnak elő 6 hónapos koruk előtt. A korai diagnózis felállításának az alkalmazott terápiában is fontos szerepe lehet, ugyanis a Na-csatornák haploinsufficientiáját eredményező funkcióvesztéssel járó mutációk (idetartoznak az MLPA-val kimutatható egy vagy több exont érintő deletiók is) jelenléte miatt a Na-csatornablokkoló típusú antiepileptikumok fokozhatják a rohamok számát, súlyosbíthatják a kórképet [16, 17, 18].

Jelen közleményben ismertetett beteg tünettanának hátterében álló génmutáció bemutatásával fel szeretnénk hívni a figyelmet egy újabb, már hazánkban is elérhető molekuláris genetikai vizsgálati lehetőségre. A hazai Dravet-szindrómás betegek molekuláris genetikai vizs- 
gálatával - amire 2013-tól lehetőség van intézetünkben - és ezt követően a genotípus-fenotípus részletes összehasonlításával értékes új információkat szerezhetünk a betegségről, ami a későbbiekben esetleg befolyásolhatja terápiás lehetőségeinket, döntéseinket.

Anyagi támogatás: A kutatás a Bolyai János Kutatási Ösztöndíj támogatásával valósult meg (ösztöndíjasok: dr. Bene Judit, dr. Komlósi Katalin).

Szerzôi munkamegosztás: B. J., K. E., M. P.: A molekuláris genetikai vizsgálatok elvégzése, értékelése. H. K., K. K.: Betegvizsgálat. B. J., K. K., H. K.: A kézirat megszövegezése. M. B.: A kézirat áttekintése. A közlemény végleges változatát valamennyi szerző elolvasta és jóváhagyta.

Érdekeltségek: A szerzőknek nincsenek érdekeltségeik.

\section{Irodalom}

[1] Vadlamudi, L., Andermann, E., Lombroso, C. T., et al.: Epilepsy in twins: insights from unique historical data of William Lennox. Neurology, 2004, 62(7), 1127-1133.

[2] Vadlamudi, L., Milne, R. L., Lawrence, K., et al.: Genetics of epilepsy: The testimony of twins in the molecular era. Neurology, 2014, 83(12), 1042-1048.

[3] Michelucci, R., Pasini, E., Riguzzi, P., et al.: Genetics of epilepsy and relevance to current practice. Curr. Neurol. Neurosci. Rep., $2012,12(4), 445-455$.

[4] Hirose, S., Mitsudome, A., Okada, M., et al.: Genetics of idiopathic epilepsies. Epilepsia, 2005, 46(Suppl. 1), 38-43.

[5] Escayg, A., Goldin, A. L.: Sodium channel $S C N I A$ and epilepsy: mutations and mechanisms. Epilepsia, 2010, 51(9), 1650-1658.

[6] Gambardella, A., Marini, C.: Clinical spectrum of SCN1A mutations. Epilepsia, 2009, 50(Suppl. 5), 20-23.
[7] Dravet, C., Bureau, M., Oguni, H., et al.: Severe myoclonic epilepsy in infancy: Dravet syndrome. Adv. Neurol., 2005, 95, 71102.

[8] Siegler, Zs., Neuwirth, M., Hegyi, M., et al.: Clinical and genetic diagnosis of Dravet syndrome: report of 20 cases. [A Dravetszindróma klinikai és genetikai diagnosztikájáról húsz esetünk kapcsán.] Ideggyogy. Sz., 2008, 61(11-12), 402-408. [Hungarian]

[9] Helbig, I., Scheffer, I. E., Mulley, J. C., et al.: Navigating the channels and beyond: unravelling the genetics of the epilepsies. Lancet Neurol., 2008, 7(3), 231-245.

[10] Marini, C., Scheffer, I. E., Nabbout, R., et al.: The genetics of Dravet syndrome. Epilepsia, 2011, 52(Suppl. 2), 24-29.

[11] Marini, C., Scheffer, I. E., Nabbout, R., et al.: SCNIA duplications and deletions detected in Dravet syndrome: implications for molecular diagnosis. Epilepsia, 2009, 50(7), 1670-1678.

[12] Shi, X., Wang, J., Kurahashi, H., et al.: On the likelihood of SCN1A microdeletions or duplications in Dravet syndrome with missense mutation. Brain Dev., 2012, 34(8), 617-619.

[13] Wang, J. W., Kurahashi, H., Ishii, A., et al.: Microchromosomal deletions involving SCNIA and adjacent genes in severe myoclonic epilepsy in infancy. Epilepsia, 2008, 49(9), 1528-1534.

[14] Nicita, F., De Liso, P., Danti, F. R., et al.: The genetics of monogenic idiopathic epilepsies and epileptic encephalopathies. Seizure, 2012, 21(1), 3-11.

[15] Zuberi, S. M., Brunklaus, A., Birch, R., et al.: Genotype-phenotype associations in $S C N 1 A$-related epilepsies. Neurology, 2011, 76(7), 594-600.

[16] Catterall, W. A., Kalume, F., Oakley, J. C.: NaVl.l channels and epilepsy. J. Physiol., 2010, 588(11), 1849-1859.

[17] Guerrini, R., Dravet, C., Genton, P., et al.: Lamotrigine and sei zure aggravation in severe myoclonic epilepsy. Epilepsia, 1998, $39(5), 508-512$.

[18] Löscher, W.: Preclinical assessment of proconvulsant drug activity and its relevance for predicting adverse events in humans. Eur. J. Pharmacol., 2009, 610(1-3), 1-11.

(Bene Judit dr., Pécs, Szigeti út 12., 7624 e-mail: bene.judit@pte.hu)

\section{A rendezvények és kongresszusok híranyagának leadása}

a lap megjelenése előtt legalább 40 nappal lehetséges, a 6 hetes nyomdai átfutás miatt. Kérjük megrendelőink szíves megértését.

A híranyagokat a következő címre kérjük: Orvosi Hetilap titkársága: Budai.Edit@akkrt.hu Akadémiai Kiadó Zrt. 